[The Editors of the Journal of General Microbiology accept no responsibility for the Reports of the Proceedings of the Society. Abstracts of papers read are published as received from authors.]

\title{
THE SOCIETY FOR GENERAL MICROBIOLOGY
}

The Society for General Microbiology held its Seventeenth General Meeting in the University of Glasgow on Tuesday and Wednesday, 15 and 16 September 1953. The following communications were made:

\section{GOMMUNIGATIONS}

A Survey of 435 Strains of Staphylococcus pyogenes. By C. LACK (Institute of Orthopaedics, University of London)

Biochemical Tests for Proteus and Providence Cultures. By Patricia H. Clarke and Constance Shaw (National Collection of Type Cultures, London)

Only a few species of intestinal bacteria (Proteus vulgaris, Pr. mirabilis, Pr. morganii and Pr. rettgeri, the Providence group, including the Wakefield bacillus, Sachs's non-mannitol-fermenting dysentery organisms, and Stuart and Wheeler's anaerogenic paracolon organism type 29911) were able to produce phenyl pyruvic acid from phenylalanine by oxidative deamination. Tests were carried out in a salt base medium containing yeast extract and $1 \%$ phenylalanine, and also with washed suspensions in buffered phenylalanine. Shigellas, salmonellas, paracolons and coliforms were usually negative, although trace reactions occurred with some salmonellas and coliforms. This test can be used as a rapid diagnostic test for Proteus and Providence.

The Proteus and Providence cultures also produced leucine decarboxylase. A simple test was devised using washed suspension and amino-acid in phthalate buffer at $\mathrm{pH}$ 5.0 with bromcresol purple as indicator. No other enterobacteria tested attacked leucine, although under these conditions many cultures decarboxylated arginine and lysine. These results suggest that the Providence group and Pr. rettgeri are very closely related to the other species of the genus Proteus.

\section{A Simple Selective Medium for the Primary Isolation of Haemophilus pertussis and parapertussis. By D. E. Nicholson and G. C. Turner (School of Medicine, Leeds)}

Bordet-Gengou medium provides excellent conditions for the growth, not only of Haemophilus pertussis, but of many other organisms commonly found on per-nasal swabs. Incorporation of penicillin suppresses some of these, but others, including $H$. influenzae, remain unaffected.

Lacey (1951) devised a semi-synthetic medium which included $4:$ 4-diamidino-diphenylamine dihydrochloride (M. \& B. 938) at $12 \mu \mathrm{g} . / \mathrm{ml}$. and which 
was highly selective for $\boldsymbol{H}$. pertussis. This has been tested over a period of 2 years with satisfactory results, but the medium is somewhat inhibitory to $\boldsymbol{H}$. pertussis, and is unreliable for the isolation of $\boldsymbol{H}$. parapertussis.

A simple selective medium, which not only allows good growth of $H$. pertussis and $\boldsymbol{H}$. parapertussis, but also largely inhibits the growth of $\boldsymbol{H}$. influenzae, can be made from horse meat extract and horse blood. Complete inhibition of $H$. influenzae and other organisms can be obtained by adding to the medium only $2 \mu \mathrm{g} . / \mathrm{ml}$. of the diamidine (which does not affect the growth of $H . p e r-$ tussis at this low concentration) and penicillin. The resulting medium is highly selective for $\boldsymbol{H}$. pertussis and $\boldsymbol{H}$. parapertussis.

$500 \mathrm{~g}$. lean horse meat (best steak) is simmered for $2 \mathrm{hr}$. with $1 \mathrm{l}$. distilled water containing $6 \mathrm{~g}$. sodium chloride. The extract is filtered hot, and to the clear fat-free filtrate is added $10 \mathrm{~g}$. Davis agar. The $\mathrm{pH}$ is adjusted to $\mathbf{7 \cdot 6}$, and oxalated horse blood, penicillin and diamidine are added at $50^{\circ}$ to give final concentrations of $20 \%, 0 \cdot 3 \mathrm{unit} / \mathrm{ml}$, and $2 \mu \mathrm{g}$. $/ \mathrm{ml}$. respectively.

So far, comparative trials show that with twenty-five positive swabs the new medium gave $26 \%$ more positive isolations than on the classical BordetGengou medium; and with just over fifty positive swabs $8.5 \%$ more positive isolations than on Lacey's medium.

\section{REFERENCE}

LACEY, B. W. (1951). J. gen. Microbiol. 5, vi.

Some Aspects of Bacteriological Standards for Foods. By J. G. DAvis (Reading)

Specific Polysaccharides of Gram-negative Bacteria. By D. A. L. Davies (Microbiological Research Department, Porton)

Specific polysaccharides have been prepared by mild acetic acid hydrolysis from antigenic trichloracetic acid extracts of some Gram-negative bacteria. The nature of the sugar residues in these materials has been examined by chromatographic methods.

The polysaccharides prepared from Shigella schmitzii and Sh. dispar contained glucosamine, galactose, glucose and rhamnose. Specific polysaccharides from $S h$. dysenteriae, $S h$. flexneri and $S h$. sonnei, which have already been described in the literature, contain glucosamine galactose rhamnose, glucosamine glucose rhamnose and glucosamine galactose glucose respectively; they thus contain glucosamine and the three possible combinations of two from the other three sugars galactose, glucose and rhamnose.

Examination of the polysaccharides extracted from eight Salmonella types having different ' $O$ ' antigenic constitutions showed that they all contained galactose, glucose, mannose and rhamnose though in different amounts; glucosamine was also present in all these materials but in very small quantities in some cases. In addition to these sugars the polysaccharides also contained one or two of the following: xylose, lyxose, an unidentified hexose, fucose and 
three unidentified deoxy-sugars. Salmonella poona specific polysaccharide contains chondrosamine and is serologically related to human blood group ' $A$ ' substance.

From eight strains of Chromobacterium violaceum polysaccharides were obtained which had little in common chemically, with the exception of two which both contained manno-gala-heptose, rhamnose and glucose; in each case the heptose composed the greater part of the material and glucose was present in small amount only. The polysaccharides from the other six strains contained from one to six of the following sugar residues: galactose, glucose, rhamnose, fucose, hexosamine, galacturonic acid, xylose, arabinose and an unidentified heptose.

\section{Changes in the Bacterial Cell Wall during Cell Division as seen in the Electron Microscope. By I. M. DAwson and H. Stern (Glasgow University)}

The stages of bacterial cell division have been followed by electron microscope examinations of the isolated cell walls of Staphylococcus aureus and Streptococcus faecalis.

In both these organisms a transverse cell-wall septum is formed which originates in and grows centripetally from the cell wall. The septum splits into two layers and division is completed by constriction of the cell wall through the line of the double septum. Cell-wall septum formation and cell-wall constriction would appear to be dissociable phenomena.

Transverse cytoplasmic membrane septa, forming before the cell-wall septum, have been demonstrated in Strept. faecalis.

\section{The Absorption of Polymyxin by Cell-wall Preparations from Pseudomonas aeruginosa. By B.A. Newton (Medical Research Council Unit for Chemical Microbiology, University of Cambridge)}

Previous studies have shown that the addition of polymyxin to washed cell suspensions of $P s$. aeruginosa caused a release of pentose, phosphate and materials which had an absorption maxima at $260 \mathrm{~m} \mu$. (Newton, 1953). No similar leakage was observed from washed cells of a resistant strain of $P$ s. aeruginosa which grew normally in $800 \mu \mathrm{g}$. polymyxin $/ \mathrm{ml}$.

Cell walls of a sensitive strain ' $S$ ' and a resistant strain ' $R$ ' were prepared by shaking washed cells, suspended in phosphate buffer, with small glass beads in a Mickle disintegrator. Cell walls of strain ' $S$ ' suspended in phosphate buffer and treated with polymyxin absorbed $330 \mu \mathrm{g}$. of the antibiotic/mg. dry weight of cell wall; this resulted in more than a $100 \%$ increase in the turbidity of the suspensions. Walls of strain ' $R$ ' absorbed less than $70 \mu \mathrm{g}$. polymyxin $/ \mathrm{mg}$. dry weight cell wall and there was little increase in turbidity of these suspensions.

Electron microscopy has shown that polymyxin treatment of strain ' $S$ ' cell walls resulted in marked changes in appearance and the antibiotic could be 
seen adhering to them. The polymyxin was firmly bound to the walls and could not be removed by repeated washing or by further shaking with glass beads in the Mickle disintegrator. No change was observed in polymyxin treated cell walls of strain ' $R$ '.

\section{REFERENCE}

Newton, B. A. (1953). J. gen. Microbiol. 9, 54.

The Effect of Arsenate upon the Bacterial Breakdown of Citrulline. By V. A. KNIvetT (Medical Research Council Unit for Chemical Microbiology, University of Cambridge and Medical Research Council Unit for Research in Cell Metabolism, University of Sheffield)

The breakdown of citrulline by cell-free extracts of Streptococcus faecalis in the presence of magnesium ions, and adenosine diphosphate (ADP) is stimulated by either phosphate or arsenate, whereas both together are inhibitory. In the presence of arsenate the breakdown of citrulline is competitively inhibited by phosphate and no ADP is required. Fluoride and $p$-chloromercury benzoate are effective inhibitors. The rate of release of $\mathrm{CO}_{2}$ from citrulline is dependent upon the concentrations of arsenate and citrulline. The disappearance of citrulline is accompanied by the formation of equimolar quantities of ornithine, $\mathrm{NH}_{3}$ and $\mathrm{CO}_{2}$.

Accelerating effects of arsenate in enzymic reactions (reviewed by Crane \& Lipmann, 1953) are taken to be due to the formation of an arsenate analogue of a phosphorylated intermediate which differs from the phosphate derivative in being readily hydrolysed. The cell-free extracts were subjected to a purification procedure, and various fractions were tested for activity in promoting citrulline breakdown $(a)$ in the presence of phosphate and ADP, and $(b)$ in the presence of arsenate. Maximum activity in $(a)$ did not coincide with maximum activity in $(b)$, and the relative activity $b / a$ varied from 0.9 to 60 . It is concluded that two enzymes are involved. In the presence of citrulline, phosphate and a 'phosphorylase', a phosphate derivative of citrulline is formed. The phosphate is transferred to ADP through the mediation of a 'phosphokinase'. The action of arsenate is attributed to the formation of an unstable arsenate derivative of citrulline by the 'phosphorylase' $(b)$.

\section{REFERENCE}

Crane, R. K. \& Lipmann, F. (1953). J. biol. Chem. 201, 235.

Some Studies on a Pyrimidine-requiring Mutant of Aerobacter aerogenes. By R. H. Nimmo-Smith (University of Oxford)

The Tricarboxylic Acid Cycle in Bacterium coli. By K. McQuillen (Department of Biochemistry, University of Cambridge)

Growing cultures of Bacterium coli strain B convert various ${ }^{14} \mathrm{C}$-labelled substrates into cellular material. Experiments with ${ }^{14} \mathrm{CO}_{2}$ (Abelson, Bolton \& Aldous, 1952) and with ${ }^{14} \mathrm{CH}_{3} \mathrm{COOH}$ and $\mathrm{CH}_{3}{ }^{14} \mathrm{COOH}$ (McQuillen \& Roberts, 1954) can be interpreted in terms of the tricarboxylic acid (TCA) cycle. 
A theoretical treatment yields flow diagrams for the various parts of the cycle, and predicts qualitatively and quantitatively the positions and activities of labelling in various products after administration of a given tracer. The flow patterns established by the use of one tracer can be checked by using others; results obtained with ${ }^{14} \mathrm{CO}_{2},{ }^{14} \mathrm{CH}_{3} \mathrm{COOH}$ and $\mathrm{CH}_{3}{ }^{14} \mathrm{COOH}$ are all mutually consistent when the same experimental conditions obtain.

During exponential growth at $37^{\circ} \mathrm{C}, 30-35 \%$ of the oxalacetate formed as an intermediate comes from $\alpha$-ketoglutarate, while the rest is formed by $\mathrm{CO}_{2}$ /pyruvate condensation. Since oxalacetate and $\alpha$-ketoglutarate (or the corresponding amino-acids) are precursors of some eight amino-acids, it appears that more than half of the protein carbon of $\boldsymbol{B}$. coli passes through some part of the TCA cycle during the synthesis of amino-acids. It is further possible to calculate that only a small fraction $(c .1 / 6)$ of the glucose carbon metabolized during growth enters the cycle, and that an even smaller fraction of the $\mathrm{CO}_{2}$ production is due to reactions of the cycle.

These findings imply that the TCA cycle in growing $B$. coli is of fundamental importance in furnishing intermediates for amino-acid synthesis, but has a minor role in carbohydrate oxidation.

This work was carried out at the Carnegie Institution of Washington in collaboration with Dr R. B. Roberts.

\section{REFERENCES}

Abelson, P. H., Bolton, E. T. \& Aldous, E. (1952). J. biol. Chem. 198, 165.

McQuillen, K. \& Roberts, R. B. (1954). J. biol. Chem. (in the Press).

The Action of Nucleic Acids on the Incorporation of Glutamic Acid by

Fragmented Staphylococcus aureus. By E. F. GALE (Medical Research Council Unit for Chemical Microbiology, University of Cambridge)

${ }^{14} \mathrm{C}$-labelled glutamic acid is incorporated into the protein fraction of disrupted staphylococcal cells if these are incubated with adenosinetriphosphate, hexosediphosphate and the labelled amino-acid in the presence or absence of a complete mixture of other amino-acids. When other amino-acids are missing, the incorporation appears to take place as a result of an exchange between the added glutamic acid and glutamyl residues of the cell protein (Gale \& Folkes, 1953; Gale, 1953). If the disrupted cells are first extracted with $\mathrm{M}-\mathrm{NaCl}$, the incorporation process is markedly increased by the addition of nucleic acid preparations worked up from the soluble portion of the cells. The nucleic acid preparation is partially inactivated by incubation with either ribonuclease or desoxyribonuclease. Ribonucleic and desoxyribonucleic acid have now been prepared from the whole staphylococcal nucleic acid, and both preparations are found to activate glutamic acid incorporation when this occurs under exchange conditions, DNA being approximately twice as effective as RNA compared on a dry weight basis.

\section{REFERENCES}

Gale, E. F. \& Folkes, J. P. (1953). Biochem. J. 55, xi.

Gale, E. F. (1953). Symp. Bacterial Metabolism. 6th int. Congr. Microbiol. p. 109. 
Some Properties of an Oxalate-decomposing Bacterium. By G. C. N.

JAYASURIYA (A.R.C. Unit for Microbiology, University of Sheffield)

A bacterium utilizing oxalate as carbon source has been isolated from soil after enrichment at $25^{\circ}$ in a medium containing $1 \%(\mathrm{w} / \mathrm{v})$ potassium oxalate and inorganic salts. The organism differs from other known oxalate decomposers by forming no red pigment (cf. Bacillus extorquens (Bassalik, 1913)) and by failing to grow on acetate or formate (cf. Vibrio oxaliticus (Bhat \& Barker, 1948); Pseudomonas oxaliticus (Janota, 1951)).

The organism grows in concentrations of potassium oxalate up to $2 \%(\mathrm{w} / \mathrm{v})$ (optimum 0.8-1.0\%) and at $\mathrm{pH}$ from 6.5 to 9.0 (optimum 7.0-8.0). Growth is preceded by a lag of about $18 \mathrm{hr}$. which cannot be reduced by the addition of yeast autolysate, bicarbonate or formate. Of several other substrates tested only glycolate, DL-lactate, pyruvate, DL-malate and succinate support growth.

Washed cells oxidize oxalate, and the gas exchanges observed correspond with an assimilation of $10 \%$ of the oxalate used. Succinate, fumarate, malate, pyruvate, lactate, acetate, glycolate and formate are also oxidized. The oxidizing powers of washed cells vary with the growth substrate, e.g. lactategrown cells oxidize lactate and glycolate more rapidly and oxalate less rapidly than oxalate grown cells.

In the presence of $0.001 \mathrm{M}$-monofluoracetate the inhibition of the rate of oxidation of glycolate and oxalate (58 and $55 \%$ ) is much greater than with acetate or pyruvate as substrate (6 and $8 \%$ ). Under these conditions glycolate gives rise to more than twice the amount of citrate obtained with pyruvate. Oxalate and acetate give no citrate. This appears to exclude the possibility that glycolate is an intermediate in the oxidation of acetate by this organism.

\section{REFERENCES}

BAssaltK, K. (1913). Jb. wiss. Bot. 53, 255.

Bhat, J. V. \& BARker, H. A. (1948). J. Bact. 55, 359.

JANota, L. (1951). Med. dośr. Mikrobiol. 2, 131. (Chem. Abs. 45, 7637).

\section{DEMONSTRATIONS}

G. Ponteconvo, J. A. Roper, R. A. Pritchard and C. E. Forbes (University of Glasgow). 'Techniques for the genetics of flamentous fungi (Aspergillus nidulans, A. niger and Penicillium chrysogenum).'

I. M. Dawson and H. Stern (University of Glasgow). 'Micrographs of changes in the bacterial cell wall during cell division.' 